Editorial

\title{
The Expert-Executive Nexus in the EU: An Introduction
}

\author{
Åse Gornitzka ${ }^{1,2, *}$ and Cathrine Holst ${ }^{2}$ \\ ${ }^{1}$ Department of Political Science, University of Oslo, 0851 Oslo, Norway; E-Mail: ase.gornitzka@stv.uio.no \\ ${ }^{2}$ Arena-Centre for European Studies, University of Oslo, 0855 Oslo, Norway; E-Mail: cathrine.holst@arena.uio.no \\ * Corresponding author
}

Submitted: 26 March 2015 | Published: 31 March 2015

Keywords

decision-making; European Union; expert knowledge

Issue

This editorial is part of the special issue "The Role of Expert Knowledge in EU Executive Institutions", edited by Professor Åse Gornitzka (University of Oslo, Norway) and Dr. Cathrine Holst (University of Oslo, Norway).

(C) 2015 by the authors; licensee Cogitatio (Lisbon, Portugal). This article is licensed under a Creative Commons Attribution 4.0 International License (CC BY).

\section{Introduction}

Expertise has played a pivotal role in EU executives since the European Union (EU) was established, but its significance is arguably increasing and takes on new shapes. This issue explores the role and use of expert knowledge in decision-making in and by EU executive institutions. Developments in the EU are decisive for executive organisation and politics in Europe, in particular due to the position of the European Commission as the EU's executive centre, but also because of the growing number of EU-level agencies. What characterizes EU's executive organizations' reliance on expert advice and judgment? How is the use of expertise organized? And what are the implications of expertise organisation for experts' performance and interactions, policy outcomes, institutional dynamics and democratic legitimacy? This introductory paper gives an overview of how these questions have been addressed in contemporary study of the European Union and serves as an introduction to the indepth analysis provided by the contributions to this special issue. But first, we explore the major argument as to why it is relevant to centre analytical attention on the nexus between expertise and executive institutions in the political-administrative systems, and second we look at why analysis of this relationship is especially warranted in the context of the EU's political-administrative order.

\section{Why Executives? Why EU? Why Expertise?}

Public administration has a central role in the preparation and implementation of public policies, and in regulating what kinds of actors, problems and solutions have access to processes of policy-making. In complex political-administrative orders, public administration has a compound role that extends across most stages of the policy process and the traditional division of powers (Vibert, 2007). Its influence lies in taking initiative, shaping the policy agenda and the policy alternatives, and drafting policy texts before formal decisions are made. Public administrative bodies also exert influence in the process of putting formal political decisions into practice, monitoring and interpreting the effects of policy and channelling feedback on how policies work back to the political-administrative system, and thus laying the foundation for new cycles of policy making. Moreover, as carriers of norms and values and basing their authority on principles of hierarchy, rule of law and expertise, bureaucracies have intrinsic value that extends beyond their instrumentality (Olsen, 2010). This institutional complexity is also evident in the EU. The overall development of the EU shows signs of an emerging executive system upheld by a politicaladministrative order that sets it apart from traditional international organizations and implies a profound transformation of executive politics within the EU (Egeberg, 2006). The European Commission (Commission) 
harbours organised capacity for policy making at the supranational level and carries most of the organizational and behavioural characteristics of "normal" executive bodies at the national level (Egeberg, 2006; Wille, 2013). With executive institutions at the EU level as a node, this executive order spans governance levels and includes multiple types of actors (Curtin \& Egeberg, 2008).

Research on the EU's multi-level administrative system relates to a wider set of issues that concerns modern political order's reliance on expert advice and judgement. In constitutional democracies the "will of the people" does not rule unfettered by concerns for other core values: rule of law, the concerns of the "past and future" as opposed to the hegemony of the present, the rights of the especially affected and $\mathrm{mi}-$ norities to be protected from the "tyranny of the majority", but also values attached to professional concerns and basing common decisions on specialized knowledge and factual evidence, to ensure their "truth-sensitivity", and so the quality of policy outcomes (Christiano, 2012; Holst \& Tørnblad, 2015 (this issue)). The starting point for this paper then is that: 1) we can expect that differences in the organization of political-administrative institutions will affect the ways in which such concerns are blended, balanced, justified and justifiable; 2) principles of expert-based decisionmaking are part of corner stone values in modern political orders, but do not necessarily find themselves in a settled position within such orders.

The role of expertise in political-administrative systems is an issue that is as perennial as it is topical, dynamic and seemingly paradoxical. On the one hand there is a demand for and expectation that policymaking should be based on evidence and facts and in accordance with, or at least guided by, what experts have to say; there is an increased scope for the particularly knowledgeable-those who know non-trivially more than most people within a domain, and that have "a capacity to deploy or exploit this fund of information to form beliefs in true answers to new questions that may be posed in the domain" (Goldman, 2011, p. 115). Knowledge production has during the previous decades grown exponentially, making the pool of specialized information potentially of relevance for policy a vast ocean of knowledge. "Knowledge-based democracies" are embedded in knowledge-based economies and societies. Different kinds of expertise are seen as essential for addressing complex problems and for managing high pace technological change and for regulation of risk prone issues and activities. The regulatory state has delegated powers to specialized agencies, staffed by purportedly neutral experts, partly based on the argument that they can carry out policies with a level of efficiency and effectiveness that politicians cannot match (Majone, 1999, p. 4). Furthermore, competent and professional bureaucracies are a key factor of quality of government and quality of life (Rothstein, 2012).
In addition, a myriad of expert advice arrangements are established and expected to contribute to enlightening and improving on the problem-solving credentials of policy- and decision-making (Fischer, 2009). Citizens seem moreover to accept decision-making on these terms as legitimate and place trust in procedures and institutions that privilege experts and expert opinions, an acceptance and trust that is intimately linked to modern society's functional expert dependency or the fact of expertise (Kitcher, 2011): It is impossibleand most people recognize that it is impossible-to make rational political decisions in complex societies like ours without relying extensively on expert advice and even expert decisions.

At the same time, the authority of professionals, scientists and science and the powers of the "unelected" appears as more contested. Professional elite monopolies in the governance of societal sectors have been under attack from an increasingly informed public in the age of mass higher education and easy access to information. In public sector reform the rule/role of professionals in welfare state governance and public bureaucracies has been challenged, and professions are perceived as self-serving "villains" producing public sector inefficiencies (Sehested, 2002). In political decision-making the distinction between beliefs based on normative views and technical knowledge are contested and blurred; is- and ought-questions, facts and values, descriptions and prescriptions are often intertwined, the argument goes. Specialized knowledge is enlisted in the service of special interests or mustered as political ammunition in adversary decision-making. Both elements of "scientization" of politics and "politicization" knowledge can be observed (Boswell, 2008; Ezrahi, 1990; Fischer, 2009; Jasanoff, 1990; Marcussen, 2006; Schofer \& Meyer, 2005; Weingart, 1999).

In the debate on the legitimacy of political orders, the tension and dependencies between "politics and expertise" has been seen as primarily relevant for inter-institutional relationships between majoritarian institutions representing the will of the people and nonmajoritarian public administration. Yet, the role of expertise is inherent in most institutions in a modern political order and more complex than a simple dyadic relationship between the elected and the unelected could lead us to believe. In the judiciary, legal professional standards and expertise are at the base of a well-functioning system and expert testimony is a recognized and integral part of it (Jasanoff, 1997). In legislative politics the elected remain "amateurs" with no special claims on specialized knowledge. However, the specialization of parliamentarians' work within sectorally specified committees, an increase in parliament staff resources, the use of public hearings, lobbyists and interest groups providing expert information, and interrogating professional news media speaking "truth to power" can be seen as signs of an increasing influx 
of specialized expertise and "expertification" processes also within the legislative branch, in civil society and the public sphere, and the development of procedures and mechanisms to hold officials, professionals and different groups of experts to account (Blichner, 2015 (this issue); Bovens, 2007; Campbell \& Laporte, 1981; Egeberg, Gornitzka, \& Trondal, 2014b; Fleischer, 2009). Consequently, framing the role of expertise in a political system as a pure antagonism versus the democratically elected, accountable political institution and (runaway) technocracy or "epistocracy" (Estlund, 2008), misses some of the core dynamics on the role of expertise and the normative complexity involved: Knowledge-based decision-making and power to expertise are not something one can be "for" or "against" per se, but rather something that is more or less legitimate or illegitimate depending on the more specific organization and behaviour of actors. This must also be the approach to the study and assessments of EU developments: the expansion of EU competencies has prompted a need for expertise in new areas and a specialization of policy-making in both the executive and the legislative branches, which has allowed for stronger every day interaction between different institutions around specialised policy issues (Egeberg, Gornitzka, \& Trondal, 2014a). On the other hand, this self-same expansion challenges existing systems and notions of democratic accountability and legitimacy. If anything, this calls for systematic investigations and analyses of how more exactly expertise is organized, institutionalized and held to account within this political order, and the implications of concrete interventions, developments and institutionalization patterns.

\section{Institutionalizing the Expertise-Executive Nexus}

For the executive branch of government there are several ways in which expertise can be organized into policy-making. This universe of organizational ways and models has been mapped and analysed in research. Our special issue contributes to this ongoing academic endeavour, but variations in organizational forms and institutionalization are also something executive organizations themselves are aware of, reflect on, and contribute to consolidate or transform, see for example Holst and Moodie (2015 (this issue)), analysing the Commission's public communication on its use of expertise and expertise organization. Generally, expertise arrangements vary in location (expertise located both within and outside the central government apparatus), in permanence (ad-hoc temporary versus permanent arrangements), in how rule-governed they are (formal or informal), and in how closely connected they are to the political centre of executive institutions. Most political-administrative systems will draw on a combination of ways of organizing expert advice (Craft \& Howlett, 2013). Executive organizations' staff represent considerable in-house expertise and the backbone of professional bureaucracies. Firstly, the degree of professionalization of bureaucracy is an indicator of executive capacity (Fukuyama, 2013). Principles and practices of meritocratic recruitment to administrative bodies and the weight given to what types of formal professional qualifications are in themselves central in defining the expert-executive nexus. Specialized and exclusive skills are at the root of the power of professions in bureaucracies and in societies at large (Christensen, 2015 (this issue)). Consequently, in order to know the role of expertise in an executive order we have to examine the extent to which bureaucrats are recruited and promoted on the basis of merit and what kind and level of technical expertise they are required to possess (Fukuyama, 2013, p. 352). As a result, changing recruitment policies and practices, such as recruiting on the basis of specialist rather than generalist qualifications in the Commission (Ban, 2010; Christensen, 2014), might both reflect and contribute to changing dynamics in EU policy-making and "technocracy". Another example is how the Commission balances meritocratic recruitment and the need for specialization and particular professional competences with other concerns, including the bureaucracy's claim to be demographically "representative" (Trondal, Murdoch, \& Geys, 2015 (this issue)).

Secondly, not only the type of in-house expertise and professional capacity is important for the expertise-executive nexus; so are the other organisational properties of bureaucracies. As participation in policymaking is defined by the formal position/offices in the organizational structure that draws up the defined sphere of competence (vertical and horizontal specialization) in line with Weberian bureaucracy as an ideal type (Weber, 1971), we can expect that expertise structures follow organisational specialisation. Bounded rationality of decision-makers in an organization means that the attention of policy makers is limited and bureaucrats' search for information trails organizational structures. Hence, contact patterns can be expected to follow bureaucratic departmental boundaries and hierarchical structures of an organization will channel the exchange and processing of information and use of expertise (Egeberg, 2012). Main information and decision-making premises come from the political and administrative leadership and from in-house expertise found within departments and agencies established under a unit's aegis.

When the use of expertise follows intra-mural organizational boundaries, it also becomes relevant to see whether capacity is organized in specialized advisory positions (permanent and temporary) or advisory units within the organization, i.e. officers or subunits that are expected to be especially oriented towards an expert role with full-time permanent staff that are specialized in producing professional advice, information, 
and knowledge. In the case of the Commission, the establishment of the Joint Research Centre has created specialized capacity for providing policy-relevant scientific input to European policy-making. The capacity for expert policy advice has also been housed in "internal think tanks" such as the Bureau of European Policy Advisers that, under the Barroso Commission, reported directly to the Commission President and operated under his authority. Such positions and units can also be reserved for particular professions, organizationally anchoring the role of specialised professional skills. Johan Christensen (2015 (this issue)) finds however that both recruitment and organizational structures of the Commission tend to emphasise specialization less than previously assumed. For example, even if there are generally more economists staffed, and so a quantitative increase, this does not necessarily imply "strong expert roles" for economists in a situation where the staff hired through economics competitions has dropped, and there are few separate units for economic analyses.

Moreover, a second important dimension in the organization of in-house expertise is the extent to which a vertical specialization has taken place, establishing specialized/regulatory agencies that are vertically separated from ministry departments and hence at arm's length from direct political steering. If organization matters, then "agencification" will tend to secure that independent expert considerations are funnelled into the policy process (Egeberg \& Trondal, 2009). Studies of the growing addition of European level agencies point to how vertical specialisation has implications for what we have labelled the backbone of bureaucracies, i.e. its staff qualifications and expertise. Studies show that in agencies recruitment and selection of staff is based on specific scientific or technical knowledge: whereas staff in the Commission tend more to be generalist-and even more generalist than commonly assumed-staff in European agencies are largely made up of specialists, with professional qualifications matching the specialisation of the Agency, such as scientists specialised in medicine, veterinary science and subareas of engineering (Suvarierol, Busuioc, \& Groenleer, 2013). Agency staff have been shown to lean towards having technocratic attitudes supporting the idea that legitimacy and accountability of EU agencies builds on expertise and should be based on professional standards, as well as on public approval of their work (Wonka \& Rittberger, 2011). Christoph Ossege's study of three European agencies (Ossege, 2015 (this issue)), shows how the expertise that regulatory agencies such as the European Medicines Agency (EMA), the European Chemicals Agency (ECHA) and the European Food Safety Authority (EFSA) draw on is a sufficient condition for policy autonomy from the Commission when providing advice. Due to the multilevel character of the EU's executive order and an increased leverage for "agents" spurred by a situation of multiple "principals", the rela- tionship between expertise and agencies' policy autonomy may even be stronger in the EU context than in comparable cases in member states or in more stringent federal systems such as the US (Zito, 2015 (this issue)).

The extramural model for bringing expert advice into policy-making also comes in several versions, be it directly through government funded research programmes, government-supported policy research centres/think-tanks, ad-hoc purchase of consultancy services or research projects, conferences, or indirectly via media, or expertise brought in through lobbying. For a supranational executive, "externalization" of expertise implies relying to a large extent on national knowledge and expertise systems and in particular the expertise housed in national administrations. Several of the contributions to this issue point to the importance and implications of experts from national administrations in several stages of the policy process. Jarle Trondal et al. (2015 (this issue)) analyse the Commission's use of a set of so-called seconded national experts (SNE), typically national civil servants bringing in knowledge of their issue area to the Commission, while at the same time communicating back their experiences and knowledge from EU executive levels to the member states. This kind of personnel is on the one hand external in the sense that they are recruited on a temporary basis from member states' administrations in areas where expertise may be lacking within the Commission's permanent staff. On the other hand they are internal to the supranational executive as they are fulltime staff of the Commission department and their de facto role conceptions as experts are significantly shaped by their supranational organizational affiliation and socialization, as well as their educational background (Trondal et al., 2015 (this issue)). Nationality and other demographic variables cannot explain how strongly such personnel are oriented towards an expert role when working for the Commission.

Expert committees are key instruments of modern governance and a paramount organized mode for channelling external input to executives at national, sub-national and supranational levels (Balla \& Wright, 2001; Craft \& Howlett, 2013; Krick, 2014), and a prominent way of organizing expertise for the executive also in the EU. Committees as collegial bodies vary in their mandate, permanence and composition, and whether they are expected to make formal and binding decisions or produce advice. Yet their implications for the expert-executive nexus are considerable. This is particularly visible in the everyday policy-making that takes place within the elaborate system of expert groups that the Commission organizes (Gornitzka \& Sverdrup, 2008; Hartlapp, Metz, \& Rauh, 2014; Metz, 2013). Within the overall institutional architecture and set of formal decision-making rules of the EU there is a considerable diversity in modes of policy making in how the everyday policies are shaped and implemented. 
Member states' government and administrative bodies are coupled to each other and with the Commission in expert groups, but such committees are also important venues through which a range of other external actors accesses the EU policy-making process (Gornitzka \& Sverdrup, 2015 (this issue); Holst \& Moodie, 2015 (this issue)). As is the case with national governments, advisory committees can be a way to address the dual challenge of securing technical expertise for policy making as well as responding to demands for representation of interests and for accountability (Krick, 2014). In the EU expert groups system, this is an "everyday" microcosmos of policy making. However, the shape and role of this part of the policy-making system varies considerably in different policy areas (Gornitzka \& Sverdrup, 2011, pp. 52-54) and issue areas. Moreover, the use of expert groups is multi-modal and extends beyond the technocratic acquisition of advice (Metz, 2013). Bart van Ballaert (2015 (this issue)) shows that the Commission uses expert groups in around $1 / 3$ of its policy initiatives and then primarily as an instrument to reduce uncertainty and not as a means to offset the salience of issues. For issues that cut across policy areas and that involve standard-setting, the lead DG is likely to make use of the expert group system. Saliency as an issue characteristic does not seem to have such an effect; there is little evidence that the DGs consult outside experts, from member states, science or interests groups-in the "narrow" space of committees and groups-in order to build consensus in contentious matters.

Also, within European agencies much of the actual work is done by external experts and scientists via committees and expert panels established as part of the formal structures of an agency. Suvarierol et al. (2013, pp. 920-921) point to how national experts participating in these committees and panels are drawn from national expert-based administrations. Their role conceptions are heavily tilted towards expertise and decisions in these fora are based on professional rules, criteria and standards rather than national interests or supranational norms. In this case "working for Europe" means basing decisions and recommendations on scientific reasoning and technical arguments. In fact, national experts taking part in the committees and panels of European agencies may come from the national level with double institutional affiliations, i.e. both national agencies and university/research institute positions. Contributions to this volume elaborate complexities in this type of nexus between experts and executives, for example in a case where national and EU agency expertise are competing and contestations are enmeshed in conflicting interests and competing ideas. Klika's analysis of the implementation of the REACH directive shows how the organized involvement of member states regulatory agencies in authorization procedures is not only based on expert assessments, but includes political considerations in the sense that national interests are explicitly represented in committee deliberations (Klika, 2015 (this issue)). However, in the end the responsible agency (in this case, the European Chemicals Agency) does not falter faced with opposition from national capitals when making its recommendations.

External experts and advisors may also be coupled to policy-making through informal structures and networks. This implies that shared norms and ideas forge the base upon which executive and external experts relate with each other in the policy process. From a cultural perspective, cultures and norms of appropriate behaviour may be as salient in shaping expertexecutive relationships as formal organisational arrangements. In knowledge utilisation research, such cultural explanations have been a starting point in accounting for "gaps" between expertise and executives (Caplan, 1979; see also Holst \& Moodie, 2015 (this issue); Rimkuté, 2015 (this issue)). Some types of information behaviour and contact patterns become institutionalized as "good administrative behaviour" and "infused with meaning" beyond the task of instrumentally seeking expert advice to policy briefs or substantiating mobilizing expert support for controversial proposals (see also Holst \& Moodie, 2015 (this issue), on the logic of "institutional decoupling"). Executive bureaucracies can thus develop departmental cultures that are conductive to epistemic orientation in policy making and shape their interaction with external expertise (see also Gornitzka \& Sverdrup, 2015 (this issue)). As a result, policy communities can be formed around individual DGs and agencies (Coen, 2007). Such communities involve a limited number of participants that share similar ideologies and values and engage in frequent and high quality interaction to an extent that they may even be referred to as "epistemic communities" (Cross, 2015 (this issue)).

For understanding the expert-executive nexus, an important line of investigation is to see how formal organisational arrangements interact with informal norms, traditions and ideas about expertise. Long engagement in expert venues can turn into sites for socialisation into common European expert cultures speaking the same expert language, merging agency staff and external experts (Suvarierol et al., 2013; see also Trondal et al., 2015 (this issue) on "resocialization" and self-perception of seconded national experts). Moreover, the role that experts can play in policy making via epistemic communities is conditional. As underlined by Mai'a Cross (2015 (this issue)), research on European integration can, on the one hand, demonstrate that the configuration of a supranational institutional set-up, shared values, and transnational interactions in Europe has been conductive to the establishment of influential knowledge-based networks of actors. In such cases, networks of experts that share specific professional behavioural rules and references-based inside or outside formal organizations-can exercise collec- 
tive agency beyond the formal mandate of their organization and be able to persuade others of policy initiatives that were not previously on the table. On the other hand, Cross' case study of EU security agencies importantly identifies the limits of expertise in influencing the trajectory of integration. She argues that the type of institutional context and type of professional background affects the propensity of networks of experts to form epistemic communities. Based on the analysis of the European Defence Agency and the EU Intelligence Analysis Centre two factors stand out in particular as limiting the possibility of forming epistemic communities: the strongly hierarchical bureaucratic structure within which experts work and the characteristics of their professions (secretive and prone not to sharing information with each other).

\section{What Type of Expertise for What Type of Executive? A Sketch of Ideal Type Models}

These different characteristics and dimensions of the expertise-executive nexus can be systematized into a set of ideal type patterns or even models that several of this special issue's contributions shed light on.

Firstly, we could talk of a supranational expertise model where policy-making takes place mainly within the executive institution itself. Here, attention is drawn to the type of expertise that the Commission and other executive bureaucracies within the EU hold and how that affects policy processes and implementation in the EU. Particularly important is how Commission' departments relate to the parallel or complementary expertise of EU agencies. This model assumes that participation in policy-making is reserved primarily for the supranational executive body itself, and in particular the Commission, as the executive centre, seeks to assert its autonomy, especially from the member states but also from other external actors. In-house professional capacity and meritocracy becomes the basis for autonomy of action for the executive and the platform for its impact on decision-making at the EU level and in inter-institutional relationships, and in the implementation of policy within the member states. Parallel to the observation of bureaucracies of national political systems, the Commission's main source of information will be its own staff and subordinate bodies, especially agencies to the extent the Commission serves as their authoritative principal. A striking example of something like this model arguably at work is a case this issue presents on the Commission's influence in an area where it interestingly does not hold formal competences. Marianne Riddervold and Hsuan Chou (2015 (this issue)) argue that the de facto influence of the Commission in the formally intergovernmental decision-making of security and defense policies and external migration is anyway substantive and captured by its use of expertise. They find that the Commission used its expert ar- guments in order to influence the member states and other actors' positions by linking intergovernmental discussions to policy areas where it holds (cross sectorial) expert authority, but also by presenting convincing expertise-based arguments. There are, however, limits to supranational expertise even in this case, since expertise as the basis for influence is used next to both institutional circumvention through informal consultations and strategic alliances with members states that share the Commission's preference for integration. Another relevant example from this special issue is analysis of how the Commission responds to criticism in its public communication on the role and use of expertise in EU policy-making. Despite a declared openness to "knowledge plurality", the Commission goes a long way in problematizing and criticizing external critics' demands for "democratizing expertise" and more inclusive expert arrangements (Holst \& Moodie, 2015 (this issue)).

Secondly, a multi-level administrative model could occur, where the Commission and EU agencies involve national ministries and other national administrative bodies in policy making through formal and informal linkages. In this model participation in policy making remains within the executive domain, but it incorporates the idea that bureaucracies are open systems that interact with their administrative counterparts from other levels of government in a multi-level executive system. The EU has taken on main hallmarks of such an executive model with frequent interpenetrations of national and European level administrations (Trondal, 2010). This multi-level administrative policymaking has two possible interpretations. It has on the one hand been argued that member states' administrations in this model capture the policy process that takes place within the European executives, not least due to the latter's dependence on a significant amount of national level expertise. This will give member states an opportunity to put their mark on policy formation and implementation beyond the institutional settings where they are formally expected to exert influence over policy decisions, that is, primarily in the Council's decision-making and in the comitology committees, where member states oversee the implementation of policy. This interpretation emphasises the interest and ability of national governments to influence, monitor, and control policy-making within the Commission.

The contention that the Commission is leaking power to national capitals in this way is at odds with the growing evidence in support of an alternative interpretation (Egeberg, 2014; Egeberg \& Trondal, 2011): This model of policy-making in the EU is an indication of a system with high level of administrative cooperation and integration and where national and EUlevel administrative bodies jointly make up an executive order. The Commission is then seen as inviting national administrations into the policy-making process in order to increase information as well as to promote 
administrative integration and interaction. For example, Trondal et al. (2015 (this issue)) can be read along these lines. Their findings on the orientation of national seconded experts in the Commission do not support the idea of national capture. Moreover, the high degree of involvement of national officials in expert committees and networks can been seen as a model for the Commission to develop a structured and organized connection with national officials, thereby also perforating national administrations. Studies of Commission expert groups find that these are not venues where policy making primarily takes place in an intergovernmental mode. This is an organized context that evokes multiple and multifaceted roles for national officials (Egeberg, Schaefer, \& Trondal, 2003), that is, they show mixed behavioural patterns that are not consistent with the idea that the Commission becomes captured by member states via this mode of policymaking. Information is shared and interpreted in organized interactions among national and Commission officials. This affects the identification of a common set of beliefs across administrative levels about the main problems and the causal mechanisms at work in a policy area (Radaelli, 2003). It implies that the Commission can draw on the national policy expertise as well as informally "sound out" the potential reception of policy proposals in national administrations. Also van Ballaert's (2015 (this issue)) findings with respect to the Commission's actual use of expert groups (to reduce uncertainty) go against the idea the expert group system represents a "nationalization" of the EU executive.

Thirdly, there is the science-oriented model, where researchers and independent scholarly experts are brought directly into the policy process; through committees, or special positions attached to different levels of the supranational executive. Here the underlying rationale is that a bureaucracy is organized to house and foster specialized expertise. However, bureaucratic organizations have limited resources as repositories of knowledge, and for gathering and processing scientific information by themselves. Thus, they are expected to link to external scientific expertise. From such a perspective, the autonomy and influence of an administration is connected to its ability to present itself as neutral, and to ground its actions in updated and specialized knowledge. The administration is seen as deriving its legitimacy from principles of enlightened, knowledge-based government, and both in-house and external experts are judged primarily on the basis of their epistemic performance (Holst \& Moodie, 2015 (this issue); Olsen, 2008). This is the case in national administrations - both national ministries and national agencies. The latter institutions in particular are organized at arm's length from a direct political steer, and have developed strong connections to parallel scientific communities and research institutions (Gornitzka, 2003). At the level beyond the nation state, interna- tional organizations in general often establish formal and informal channels for scientific input to the policy process (Andresen, 2000; Haas, Williams, \& Babai, 1977). Scientific expertise has the added attraction as a source of information because it may transcend the bias of information imbued with national interests. This latter aspect would also apply to EU executive institutions. In the EU, increased complexity and "technical" uncertainty in governing modern societies have increased the role of scientific arguments and the role of expertise (Ballaert, 2015 (this issue); Radaelli, 1999). The nexus between the European executive and scientists underlines the European administrative system as an epistemic, scientized space. Drawing on scientists as the main information providers would thus legitimize the executive bodies' autonomous basis for action, independent of national, societal, and partisan interest, and would potentially buffer it from the political and intergovernmental logic of policy making. In an EU executive context, this would seem to apply not least in the case of the agencies: The horizontal specialization involved in establishing (semi)independent regulatory agencies can be expected to affect the organizational foothold that science has within an executive order. That is, given that the agency level has in many cases the formal task of providing science-based advice and regulatory decisions, how agencies actually use scientific expertise is consequently a key to understanding the science-oriented expert executive nexus. Several of the cases discussed in this issue also point to how the presence of agencies at the European level have implications for how science is funneled into decisionmaking and the implications of this not least for agency-Commission interactions. As argued, for instance, in the case of ECHA, EMA and EFSA (Ossege, 2015 (this issue)), the scientific expertise that these agencies draw on is the basis for their ability to maintain an independent advisory role vis-à-vis the Commission.

A further step towards uncovering the mechanisms involved in the use of scientific expertise is provided by Rimkuté (2015 (this issue)). She analyses how a European agency's (European Food Safety Authority) use of scientific expertise is affected by pressures from its external environment and the agency's internal expert capacity. She finds that in the case of pesticide regulation where the Agency had strong internal capacity to produce scientific advice (the EFSA's Pesticide Unit), but was faced with controversy among political actors and differing scientific conclusions, the Agency used scientific evidence in a "strategic substantiating mode". The Commission's position as risk regulator and as the most important actor in EFSA's environment defined new and stricter standards of risk assessment (precautionary principle) which in turn led the agency to rely on one type of scientific evidence over another. On a general level, this demonstrates that the use of scientific expertise has to be theorized and analyzed by tak- 
ing into consideration internal organizational factors as well as environmental and case specific conditions.

However, there are also limits to scientizaton: Expert dependence that several of the cases analyzed in this special issue refer to does not necessarily lead to scientific expertise trumping other decision making premises in inter-institutional decision making at the supranational level. The Commission's proposal for regulating trade on Seal products is illustrative (Blichner, 2015 (this issue)): The proposal was based on internal and external scientific assessments but was challenged by the European Parliament and pressure groups on ethical grounds/and with reference to assessment of science from a perspective of animal welfare. This indicates that scientization of policy making is conditional-depending on the types of policies or issues, what level of specialized expertise they are seen to demand, epistemic uncertainty as well as on degree of politicization.

Finally, there is the "society" model that assumes a direct relationship between societal actors and public administration, tight links between supranational executive bureaucracies, societal, non-governmental actors, including consultations with private corporations and businesses, EU social partners, and civil society associations. A pluralist idea suggests that societal interests and affected parties have a legitimate right to be heard and have their views taken into consideration. The authority and legitimacy of executive bodies are derived from opening up to, channelling, and mediating different political forces, that is, it reflects deference to principles of input legitimacy, representation of societal interests, and attention to experience-based expertise. Administrators need information and support from such groups for making and defending their policies in their relationships with other political institutions; and such groups can use these organized links to further their interests and perspectives on policy issues (Peters, 1995, p. 181). As is the case in national administrations, the Commission will be interested in cultivating a relationship with business groups and organized interests as providers of information about grass-root preferences and of factual information in complex policy areas (Bouwen, 2004; Broscheid \& Coen, 2007; Coen, 2007). Societal groups make claims to represent specialized and professional information as well as experiential expertise (Greenwood, 2007).

Several studies report a triangular relationship between expertise, executives and society at several levels and stages of the policy processes. The role of adhoc expert venues is a case at hand. Commission expert groups bring national officials from corresponding ministries and agencies into interaction with Commission departments. As highlighted earlier, the externalization of expertise that takes place within the expert groups are in this way embedded in a multi-level administrative system (Gornitzka \& Sverdrup, 2015 (this issue)). However, as societal actors take part in 40 percent of all expert groups the overall pattern of participation in expert venue is consistent also with the Commission as a societal responsive executive that bring into policy making a mix of different types of actors. "Pure" society oriented expert groups are indeed rare, but societal representation from industry, "social partners" or NGOs are frequently blended with participation from scientists and academics. Also the factors that prompt Commission departments to include "society" differ between types of societal actors: the logic of inclusion of industry and corporate actors into expert venues is different from the logic applied to, for instance, NGOs. Overall these findings suggest considerable heterogeneity in the European executive's link to external expertise in the preparatory and implementing stages of the policy process. Also the role of expertise plays out differently for European agencies when they deal with private stakeholders than with their Commission parent or partner departments. Visà-vis the latter, the European Medicine Agency, European Chemicals Agency and the European Food Safety Authority's superior specialized expertise guards their policy autonomy, whereas with strong private stakeholder with considerable technical and scientific capacity of their own, agencies engage in procedural insulation in order to protect their independence (Ossege 2015 (this issue)).

\section{Assessing Expertise in Executives: Normative Justification and Institutional Variation}

Finally, there is the question of how to assess the normative legitimacy of EU expertise arrangements, andkey for this special issue-how this question of the legitimate, or illegitimate, use and role of expertise and experts in policy-making is linked to different dimensions of the organization and institutionalization of the expertise-executive nexus. Generally, questions of normative legitimacy and justification depend decisively on choice of justification criteria. Holst and Tørnblad (2015 (this issue)) introduce a distinction between intrinsic and epistemic justifications of democratic systems (Estlund, 2008; Goodin, 2003; Lafont, 2006; Peter, 2011): To be a desirable form of rule, democracy must have procedures with "truth-tracking" or "truthsensitive" qualities that contribute to improving on decisions, but a normative defense of democracy must also refer to the intrinsic moral value of democratic procedures. It follows from this that the organization and institutionalization of expert arrangements within such systems must both fulfill certain democratic procedural requirements and score well on performance parameters. Holst and Tørnblad contribute primarily to the latter in their discussion of how to assess and measure the epistemic quality of EU experts' deliberations in the context of the Commission's expert group system. 
Their concern overlaps significantly with Klika's (2015 (this issue)), as he discusses the viability of European Chemicals Agency consultation and decision procedures in light of deliberative expectations and criteria-what he refers to as "throughput legitimacy", framed as an alternative to standard notions of input and output legitimacy. There is a similar focus in the work of Blichner (2015 (this issue)), who develops a set of tests citizens and their representatives can use to hold experts to account under conditions of epistemic asymmetry (see also Holst \& Tørnblad, 2015 (this issue)).

Blichner's, Klika's and Holst and Tørnblad's contributions are all illustrative of the intimate interconnections between normative assessments and organizational and institutional analysis. Blichner operationalizes his list of accountability tests in the institutional context of European Parliament-Commission interactions. Klika clarifies levels of throughput legitimacy by means of a detailed examination of formal and informal aspects of the ECHA, its procedures and the multilevel institutional context in which it is embedded; Holst and Tørnblad highlight the close relationship between experts' deliberative performance and institutional variables, and discusses ways to tackle the issue in empirical research. This highlights a common underlying point: In assessments of the normative legitimacy of expert arrangements, a set of organizational and institutional characteristics of the expertise-executive nexus will be relevant to look at, and several contributions to this volume bring our attention to how and why this is so, raising the issue quite explicitly or in more implicit terms.

First, when evaluating experts' performance and the epistemic merits of particular expertise-based bodies or procedures, what kind of experts and expertise that are consulted or delegated power on what kind of issues, is of significant importance. This is a key normative subtext in Christensen's (2015 (this issue)) contribution. If generalists are what the Commission needs to perform its task in an optimal way, recruitment of generalists are in full order. However, if the Commission's staff is also supposed to perform specialized, technical tasks that needs highly skilled specialists ready to fill "strong expert roles", current recruitment practices are more problematic.

Secondly, there is the separate question of which issues experts of whatever kind should be given extra political power on, whether they are consulted, for example as part of expert groups or committees, or whether they are delegated discretionary space to make decisions and formulate and implement policies, for example as part of the in-house expertise of an executive agency. A central, but far from clear-cut distinction runs between technical questions, questions of state of affairs, causal dynamics, and "what works", and standard-setting questions of how to conceptualize, rank and interpret principles, values and goals; between instrumental means-end issues and the moral and political issue of which ends we ought to pursue, and how we can do so in normatively defensible ways. A standard assumption in democratic theory is that the latter are questions for citizens, not for experts, for intrinsic democratic reasons, and because there cannot be "moral experts" (Dahl, 1989; Kitcher, 2011), or if there can be such a thing (Broome, 2012; Singer, 1972) the ones we should have in mind are not necessarily the technical "what works" experts. However, closer examinations and analyses of the questions experts actually engage with, also found in the contributions to this special issue (see for example Rimkuté, 2015 (this issue), van Ballaert, 2015 (this issue), Zito, 2015 (this issue)) give firm evidence that experts are routinely involved in standard-setting practices and enter "the kingdom of ends", be it because they are formally entitled to do so, because they do so informally, with conscious intent, or because they consider it "appropriate", push the limits of their mandates (as full-fledged "epistemic communities" typically would tend to do, see Cross, 2015 (this issue)), or because facts and values in many cases are inevitably intertwined. This raises obvious questions of normative legitimacy, and is a natural concern also for Blichner (2015 (this issue)) in his discussion of expert accountability in the seal ban case (see also Holst \&Tørnblad, 2005 (this issue)).

Thirdly, as already suggested, both formal mandate and organization and more informal features of the institutionalization of expert cultures also need to be considered for normative reasons. It is arguably problematic for executives to seek extensive recourse to expert authority arguments of the kind Riddervold and Chou (2015 (this issue)) outline even within the domain of their formal competences, but even more problematic when they do so beyond it. Moodie and Holst (2015 (this issue)) highlight how actual Commission communication practices of subtly avoiding unpleasant facts contradict official statements of openness and transparency and cherished ideas of how knowledge utilization is to serve problem-solving and enlightenment. A normative analysis of EU executive/citizen relations will be meager if it fails to consider such informal features of accountability.

Fourthly, several of the contributors of this special issue address or touch upon the democratic merits of EU-expert arrangements. This is an underlying normative concern for Trondal et al. (2015 (this issue)) when they discuss the Commission's use of expertise from a representative bureaucracy perspective, as well as for Gornitzka and Sverdrup (2015 (this issue)) in their mapping and analysis of societal and stakeholder participation patterns in the Commission's expert groups system. Also Blichner (2015 (this issue)) could exemplify: His expert accountability tests are developed to ensure a high quality of political decisions under conditions of expertise dependence and epistemic asymmetry, but also no doubt reflect deeper concerns for democratic equality. 


\section{Acknowledgements}

We gratefully acknowledge the contributions of the authors in this special issue and also the many excellent reviewers that generously shared their comments, criticisms and ideas in the process of making this special issue. We also thank the participants of the seminar at the Department of Politics Science, University of Oslo, $10^{\text {th }}$ March 2015, where a preliminary version of this editorial was presented. Finally, without the professionalism of António Vieira this special issue would not have been possible.

\section{Conflict of Interests}

The authors declare no conflict of interests.

\section{References}

Andresen, S. (2000). Science and politics in international environmental regimes: Between integrity and involvement. Manchester: Manchester University Press.

Balla, S. J., \& Wright, J. R. (2001). Interest Groups, advisory committees, and congressional control of the bureaucracy. American Journal of Political Science, 45(4), 799-812. doi: $10.2307 / 2669325$

Ballaert, B. v. (2015). The politics behind the consultation of expert groups: An instrument to reduce uncertainty or to offset salience? Politics and Governance, 3(1), 139-150.

Ban, C. (2010). Reforming the staffing process in the European Union institutions: Moving the sacred cow out of the road. International Review of Administrative Sciences, 76(1), 5-24. doi: 10.1177/002085 2309359042

Blichner, L. C. (2015). Epistemic dependence and the EU seal ban debate. Politics and Governance, 3(1), 49-60.

Boswell, C. (2008). The political functions of expert knowledge: Knowledge and legitimation in European Union immigration policy. Journal of European Public Policy, 15(4), 471-488. doi: 10.1080/135017 60801996634

Bouwen, P. (2004). The logic of access to the European Parliament: Business lobbying in the committee on economic and monetary affairs. Journal of Common Market Studies, 42(3), 473-496.

Bovens, M. (2007). Analysing and assessing accountability: A conceptual framework. European Law Journal, 13(4), 447-468. doi: 10.1111/j.1468-0386.2007. 00378.x

Broome, J. (2012). Climate matters: Ethics in a warming world. New York: W.W. Norton.

Broscheid, A., \& Coen, D. (2007). Lobbying activity and fora creation in the EU: Empirically exploring the nature of the policy good. Journal of European Pub- lic Policy, 14(3), 346-365.

Campbell, S., \& Laporte, J. (1981). The staff of the parliamentary assemblies in France. Legislative Studies Quarterly, 6(4), 521-531.

Caplan, N. (1979). The two-communities theory and knowledge utilization. American Behavioral Scientist, 22(3), 459-470.

Christensen, J. (2014). Recruitment and expertise in the European Commission. West European Politics, 38(3), 1-30. doi: 10.1080/01402382.2014.982353

Christensen, J. (2015). The organization of professional expertise in the European Commission. Politics and Governance, 3(1), 13-25.

Christiano, T. (2012). Rational deliberation among experts and citizens. In J. Parkinson \& J. Mansbridge (Eds.), Deliberative systems: Deliberative democracy at the large scale (pp. 27-51). Cambridge: Cambridge University Press.

Coen, D. (2007). Empirical and theoretical studies in EU lobbying. Journal of European Public Policy, 14(3), 333-345. doi: 10.1080/13501760701243731

Craft, J., \& Howlett, M. (2013). The dual dynamics of policy advisory systems: The impact of externalization and politicization on policy advice. Policy and Society, 32(3), 187-197. doi: http://dx.doi.org/10. 1016/j.polsoc.2013.07.001

Cross, M. a. K. D. (2015). The limits of epistemic communities: EU security agencies. Politics and Governance, 3(1), 90-100.

Curtin, D., \& Egeberg, M. (2008). Tradition and innovation: Europe's accumulated executive order. West European Politics, 31(4), 639-661. doi: 10.1080/01 402380801905868

Dahl, R. A. (1989). Democracy and its critics. New Haven, Conn.: Yale University Press.

Egeberg, M. (2006). Europe's executive centre in the melting pot: An overview. In M. Egeberg (Ed.), Multilevel Union administration (pp. 1-16). Houndmills: Palgrave.

Egeberg, M. (2012). How bureaucratic structure matters: An organizational perspective. In B. G. Peters \& J. Pierre (Eds.), The Sage handbook of public administration (2nd ed., pp. 157-168). London: Sage.

Egeberg, M. (2014). The European Commission: From agent to political institution. Public Administration, 92(1), 240-246. doi: 10.1111/padm.12094

Egeberg, M., Gornitzka, Å., \& Trondal, J. (2014a). A not so technocratic executive? Everyday Interaction between the European Parliament and the Commission. West European Politics, 37(1), 1-18. doi: http://dx.doi.org10.1080/01402382.2013.832952

Egeberg, M., Gornitzka, A., \& Trondal, J. (2014b). People who run the European Parliament: Staff demography and its implications. Journal of European Integration, 36(7), 659-676.

Egeberg, M., Schaefer, G. F., \& Trondal, J. (2003). The many faces of EU committee governance. West Eu- 
ropean Politics, 26(3), 19-40.

Egeberg, M., \& Trondal, J. (2009). Political leadership and bureaucratic autonomy: Effects of agencification. Governance, 22(4), 673-688. doi: 10.1111/ j.1468-0491.2009.01458.x

Egeberg, M., \& Trondal, J. (2011). EU-level agencies: New executive centre formation or vehicles for national control? Journal of European Public Policy, 18(6), 868-887. doi: 10.1080/13501763.2011.593314

Estlund, D. M. (2008). Democratic authority: A philosophical framework. Princeton, N.J.: Princeton University Press.

Ezrahi, Y. (1990). The descent of Icarus: Science and the transformation of contemporary democracy. Cambridge, Mass.: Harvard University Press.

Fischer, F. (2009). Democracy and expertise: Reorienting policy inquiry. Oxford: Oxford University Press.

Fleischer, J. (2009). Power resources of parliamentary executives: Policy advice in the UK and Germany. West European Politics, 32(1), 196-214. doi: 10. 1080/01402380802509941

Fukuyama, F. (2013). What is governance? Governance, 26(3), 347-368. doi: 10.1111/gove.12035

Goldman, A. I. (2011). Experts: Which ones should you trust? In A. I. Goldman \& D. Whitcomb (Eds.), Social epistemology: Essential readings (pp. 109-135). Oxford Oxford University Press.

Goodin, R. E. (2003). Reflective democracy. Oxford: Oxford University Press.

Gornitzka, A. (2003). Science, clients, and the state: $A$ study of scientific knowledge production and use. Enschede: CHEPS.

Gornitzka, A.., \& Sverdrup, U. (2008). Who consults? The configuration of Expert Groups in the European Union. West European Politics, 31(4), 725-750.

Gornitzka, Å., \& Sverdrup, U. (2011). Access of experts: Information and EU decision-making. West European Politics, 34(1), 48-70.

Gornitzka, Å., \& Sverdrup, U. (2015). Societal inclusion in expert venues: participation of interest groups and business in the European Commission expert groups. Politics and Governance, 3(1), 151-165.

Greenwood, J. (2007). Organized civil society and democratic legitimacy in the European Union. British Journal of Political Science, 37(02), 333-357. doi: doi:10.1017/S0007123407000166

Haas, E. B., Williams, M. P., \& Babai, D. (1977). Scientists and world order: The uses of technical knowledge in international organizations. Berkeley: University of California Press.

Hartlapp, M., Metz, J., \& Rauh, C. (2014). Which policy for Europe? Power and conflict inside the European Commission. Oxford, Oxford University Press.

Holst, C., \& Moodie, J. (2015). Cynical or deliberative? An analysis of the European Commission's public communication on its use of expertise in policymaking. Politics and Governance, 3(1), 37-48.
Holst, C., \& Tørnblad, S. H. (2015). Variables and challenges in assessing EU experts' performance. Politics and Governance, 3(1), 166-178.

Jasanoff, S. (1990). The fifth branch-Science advisers as policymakers. Cambridge MA: Harvard University Press.

Jasanoff, S. (1997). Science at the bar: Law, science, and technology in America. Cambridge, Mass.: Harvard University Press.

Kitcher, P. (2011). Science in a democratic society. Amherst, N.Y.: Prometheus Books.

Klika, C. (2015). The implementation of the REACH authorisation procedure on chemical substances of concern: What kind of legitimacy? Politics and Governance, 3(1), 128-138.

Krick, E. (2014). Negotiated expertise in policy-making: How governments use hybrid advisory committees. Science and Public Policy. doi: 10.1093/scipol/scu069

Lafont, C. (2006). Is the ideal of deliberative democracy coherent? In S. Besson \& J. L. Martí (Eds.), Deliberative democracy and its discontents. Hampshire, England: Ashgate Publishing Itd.

Majone, G. (1999). The regulatory state and its legitimacy problems. West European Politics, 22(1), 1-24. doi: 10.1080/01402389908425284

Marcussen, M. (2006). Institutional Transformation? The scientization of central banking as a case study. In T. Christensen \& P. Lægreid (Eds.), Autonomy and regulation: Coping with agencies in the modern state (pp. 81-109). Cheltenham: Edward Elgar.

Metz, J. (2013). Expert groups in the European Union: A sui generis phenomenon? Policy and Society, 32(3), 267-278.

Olsen, J. P. (2008). The ups and downs of bureaucratic organization. Annual Review of Political Science, 11, 13-37.

Olsen, J. P. (2010). Governing through institution building. Institutional theory and recent European experiments in democratic organization. Oxford: Oxford University Press.

Ossege, C. (2015). Driven by expertise and insulation? The autonomy of European regulatory agencies. Politics and Governance, 3(1), 101-113.

Peter, F. (2011). Democratic legitimacy. New York, N.Y.: Routledge.

Peters, B. G. (1995). The politics of bureaucracy. New York: Longman Publishers USA.

Radaelli, C. M. (1999). The public policy of the European Union: Whither politics of expertise? Journal of European Public Policy, 6(5), 757-774.

Radaelli, C. M. (2003). The open method of coordination: A new governance architecture for the European Union? SIEPS (Vol. 1). Stockholm: Swedish Institute for European Policy Studies.

Riddervold, M., \& Chou, M.-H. (2015). The unexpected negotiator at the table: How the European Commission's expertise informs intergovernmental EU 
policies. Politics and Governance, 3(1), 61-72.

Rimkuté, D. (2015). Explaining differences in scientific expertise use: The politics of pesticides. Politics and Governance, 3(1), 114-127.

Rothstein, B. (2012). Political legitimacy for public administration. In B. G. Peters \& J. Pierre (Eds.), The Sage handbook of public administration (2nd ed., pp. 407-419). London: Sage Publications.

Schofer, E., \& Meyer, J. W. (2005). The worldwide expansion of higher education in the twentieth century. American Sociological Review, 70(6), 898-920.

Sehested, K. (2002). How new public management reforms challenge the roles of professionals. International Journal of Public Administration, 25(12), 1513-1537. doi: 10.1081/PAD-120014259

Singer, P. (1972). Moral experts. Analysis, 32(4), 115117.

Suvarierol, S., Busuioc, M., \& Groenleer, M. (2013). Working for Europe? Socialization in the European Commission and Agencies of the European Union. Public Administration, 91(4), 908-927. doi: 10.1111/j.1467-9299.2012.02100.x

Trondal, J. (2010). An emergent European exective order. Oxford: Oxford University Press.
Trondal, J., Murdoch, Z., \& Geys, B. (2015). Representative bureaucracy and the role of expertise in politics. Politics and Governance, 3(1), 26-36.

Vibert, F. (2007). The rise of the unelected: democracy and the new separation of powers. Cambridge: Cambridge University Press.

Weber, M. (1971). Makt og byråkrati: Essays om politikk og klasse, samfunnsforskning og verdier. Oslo: Gyldendal.

Weingart, P. (1999). Scientific Expertise and political accountability: Paradoxes of science in politics. Science and Public Policy, 26(3), 151-161.

Wille, A. (2013). The normalization of the European Commission. Politics and bureaucracy in the EU executive. Oxford: Oxford University Press.

Wonka, A., \& Rittberger, B. (2011). Perspectives on EU governance: An empirical assessment of the political attitudes of EU agency professionals. Journal of European Public Policy, 18(6), 888-908. doi: 10.1080/13501763.2011.593315

Zito, A. R. (2015). Expertise and power: Agencies operating in complex environments. Politics and Governance, 3(1), 73-89.

\section{About the Authors}

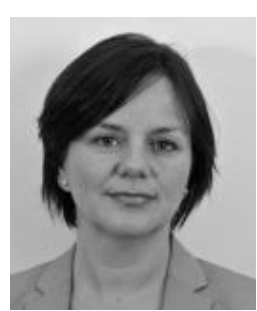

\section{Dr. Åse Gornitzka}

Åse Gornitzka is a Professor at the Department of Political Science, University of Oslo, and Research Professor at Arena, Centre for European Studies, University of Oslo. She is also Adjunct Professor at the Department of Administration and Organization Theory, University of Bergen, and Editor-in-Chief of Scandinavian Political Studies. Her main fields of research include the role of organisational factors in EU governance, administrative integration and transformation in Europe, as well as the comparative study of national public reforms and change in public sector organisations.

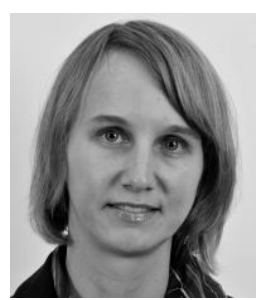

\section{Dr. Cathrine Holst}

Cathrine Holst is a Senior Researcher at ARENA-Centre for European Studies, University of Oslo where she coordinates the project Why not epistocracy? (EPISTO). Holst's research interests are democratic theory, political epistemology, expertise politics, European studies, and gender studies. Recent publications are "Why democracy? On the relationship between gender democracy and gender equality in the EU", and "Jürgen Habermas on public reason and religion: Do religious citizen suffer an asymmetrical cognitive burden, and should they be compensated?" (with Anders Molander). 